\title{
Tracking a big anticyclonic eddy in the western Mediterranean Sea*
}

\author{
JORDI FONT, JORDI ISERN-FONTANET, and JOSE DE JESUS SALAS \\ Institut de Ciències del Mar, CMIMA-CSIC, Passeig Marítim de la Barceloneta 37-49, 08003 Barcelona, Spain. \\ E-mail: jfont@icm.csic.es
}

\begin{abstract}
SUMMARY: In May 1998 a big and deep open ocean anticyclonic eddy (AE 98-1) was sampled in the Algerian basin (western Mediterranean sea) in a region south of the Balearic islands. Fifteen surface Lagrangian buoys, tracked by satellite, were released across the eddy and were used for a few months to observe the continuity of the anticyclonic motion and the westward drift of the eddy. This kind of big and intense eddies in the Mediterranean can be detected by satellite altimeter radars. Using a new method, based on the Okubo-Weiss criterion, to identify mesoscale eddies in Sea Level Anomaly maps derived from measurements of the ERS and TOPEX/POSEIDON altimeters, an independent tracking of the same eddy was performed. There is a remarkable agreement between the two results despite the different nature of the information, mainly due to the fact that SLA maps contain interpolated and smoothed measurements while the drifters' trajectories are in situ data obtained from individual drifter fixes. The location of the eddy centre during two months with the two methods agrees within an average distance lower than the spatial resolution of the altimetric maps $\left(0.2^{\circ}\right)$. The size of the eddy, when it is possible to determine it, is also highly coincident in both cases (96.5\% in diameter), and its average westwards translation speed is reasonably similar ( $24 \%$ lower from drifters). These results can be considered a good validation of the new tracking method in SLA maps in this specific case.
\end{abstract}

Key words: Mediterranean sea, Algerian basin, mesoscale eddies, Lagrangian drifters, satellite altimetry

RESUMEN: En mayo de 1998 un gran remolino anticiclónico de mar abierto fue observado al sur de las islas Baleares, en la cuenca Argelina (mar Mediterráneo occidental). Quince boyas superficiales de deriva fueron lanzadas a través del remolino, y su localización por satélite durante varios meses permitió seguir la continuidad del movimiento anticiclónico y el desplazamiento del remolino hacia el oeste. Este tipo de remolinos intensos puede ser detectado mediante radares altimétricos desde satélite. Un nuevo método, basado en el criterio de Okubo-Weiss, ha permitido seguir este mismo remolino en una serie de mapas de anomalías del nivel del mar obtenidos a partir de observaciones de los satélites ERS y TOPEX/POSEIDON. A pesar de que la información de los mapas altimétricos está interpolada y suavizada, y en cambio las trayectorias de los flotadores se han determinado a partir de localizaciones puntuales, se ha encontrado una concordancia notable entre ambos tipos de resultados. La posición del centro del remolino determinada con ambos métodos durante dos meses presenta unas diferencias que en promedio son menores que la resolución espacial de los mapas altimétricos $\left(0.2^{\circ}\right)$. El tamaño del remolino, cuando es posible calcularlo, es altamente coincidente $(96.5 \%$ del diámetro), mientras que su velocidad de desplazamiento hacia el oeste es razonablemente parecida (24\% inferior cuando se calcula a partir de los flotadores). Estos resultados pueden considerarse como una buena validación del nuevo método de seguimiento de remolinos de mesoescala en mapas altimétricos en el caso particular estudiado.

Palabras clave: Mar Mediterráneo, cuenca Argelina, remolinos de mesoescala, flotadores Lagrangianos, altimetría por satélite.

\section{INTRODUCTION}

The Mediterranean Sea circulation is characterised by the presence of three different scales. At a

*Received December 10, 2003. Accepted March 5, 2004. large scale the circulation is of thermohaline nature, due to the global dominance of evaporation over runoff and precipitation, and the compensating exchange through the strait of Gibraltar. At a regional scale the different meteorological and topographic characteristics configure specific circulation pat- 


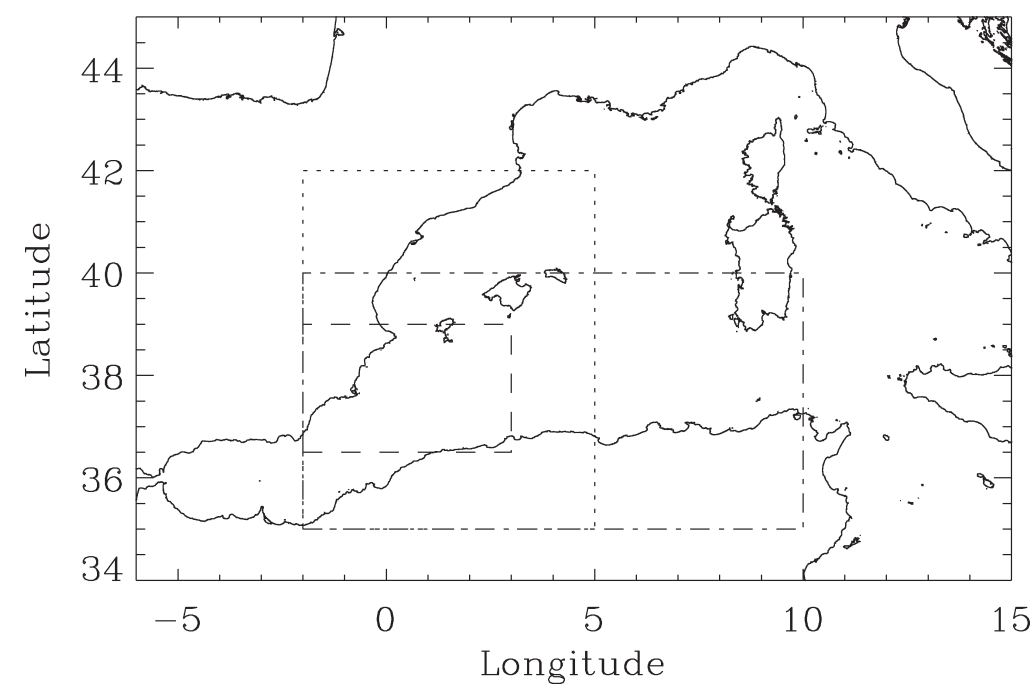

FIG. 1. - The Algerian basin (dashed-dotted line, area as in Fig. 7) in the western Mediterranean Sea. The dotted line indicates the region where the Lagrangian buoys were drifting (Figs. 5 and 6) and the dashed line the area where the eddy tracking is analysed in this paper (Figs. $3,4,8$ and 9)

terns in the Mediterranean subbasins. Finally, as was first pointed out by Millot (1987) from the observation of satellite infrared imagery, an important mesoscale variability gives rise to the generation of meanders, eddies, filaments and other structures that can greatly influence the circulation in some areas. The Algerian Basin, in the south of the western Mediterranean (Fig. 1) and open to the effects of the surface waters incoming from the Atlantic, is domi- nated by the presence and evolution of intense mesoscale eddies and not by any stable or well defined stream or current system.

After meandering in a wave-like front in the Alboran sea, the incoming flow of Atlantic water forms a narrow eastward current along the Algerian coast (Fig. 2). This density flow of low salinity water, the Algerian Current (Millot, 1985), becomes unstable and generates coastal eddies that propagate with the

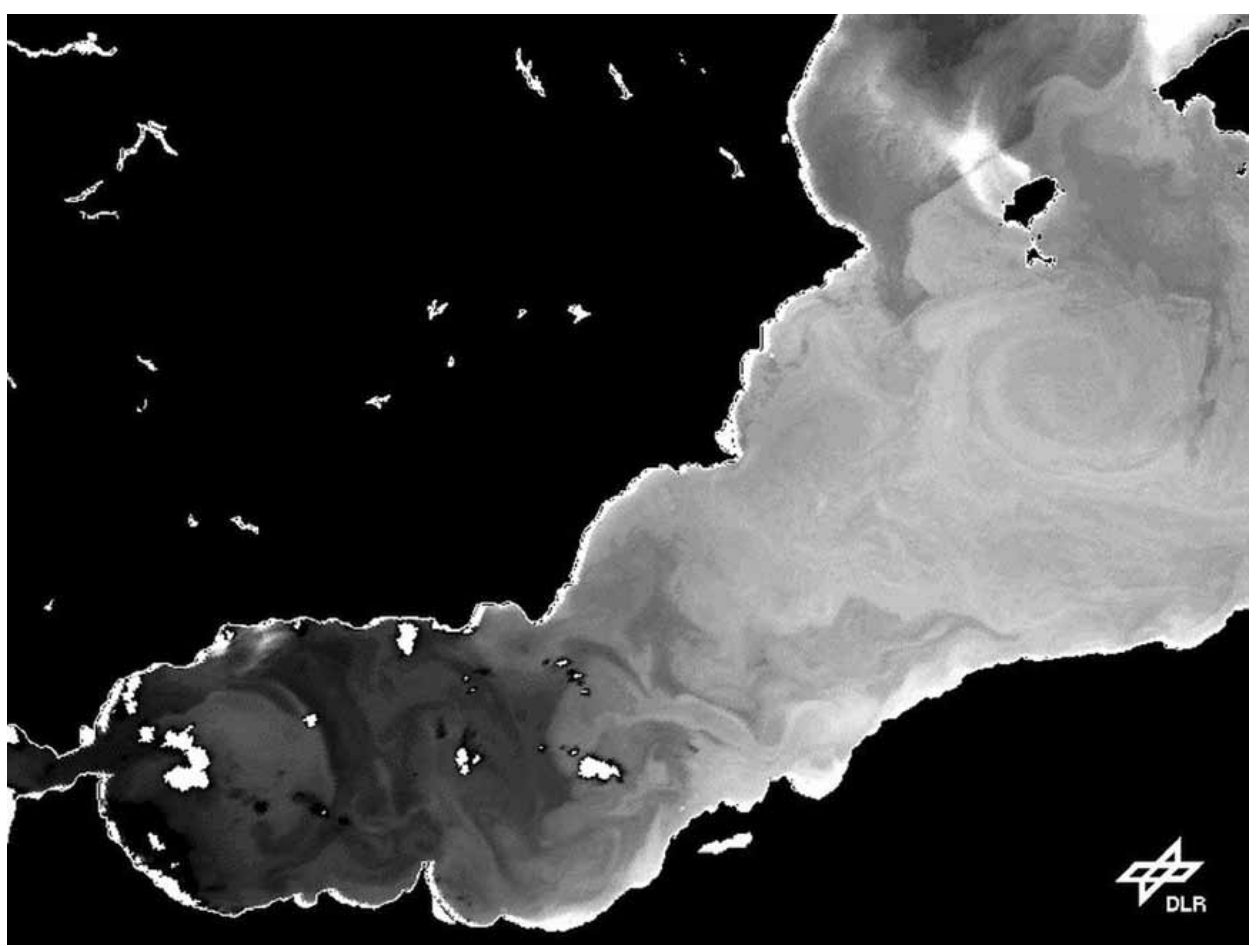

FIG. 2. - Sea surface temperature of the western Algerian basin as measured by NOAA/AVHRR on 7 May 1998. The anticyclonic eddy can be observed south of the Balearic Islands. Image downloaded from the GISIS public server, DLR Germany 
current at a few $\mathrm{km}$ per day (Obaton et al., 2000; Salas et al., 2002). Some large eddies are associated with a deep anticyclonic motion and, usually at the entrance of the Sardinia Channel near $9^{\circ} \mathrm{E}$, they are forced by topography to detach from the coast and evolve as open sea anticyclonic eddies over the Algerian basin (Millot et al., 1997). These structures, named Algerian Eddies (AEs), have variable diameters of about 100-200 km, vertical extents from 100s to $1000 \mathrm{~s}$ of $\mathrm{m}$, translation speeds of up to $3-5 \mathrm{~km} / \mathrm{d}$, and associated surface velocities of $30-50 \mathrm{~cm} / \mathrm{s}$. They are also long-lived, in some cases with reported lifetimes of nearly 3 years (Benzohra and Millot, 1995; Fuda et al., 2000; Ruiz et al., 2002; Puillat et al., 2002). AEs not only have a crucial impact on the Algerian basin circulation, but their associated biological response is also very remarkable (Morán et al., 2001; Taupier-Letage et al., 2003).

Most of the information on AE size and evolution has been obtained using infrared and colour satellite imagery (e.g. Millot, 1985; Arnone and La Violette, 1986; Taupier-Letage and Millot, 1988) because of the scarcity of hydrographic measurements in the area. In fact, although in situ sampling is the only way to characterise the full structure of the eddies, and moored current meters can provide information on their deep motion (Millot et al., 1997), remote sensing is the best-suited tool for tracking the eddies' evolution through their surface signature. Usually thermal differences between the waters of Atlantic origin trapped inside the AEs and the Mediterranean waters that surround them have allowed satellite infrared imagery to use temperature as a tracer to identify eddies, especially in a region of low cloud cover like the Algerian basin (Puillat et al., 2002). Also, enhanced biological activity in relation to these mesoscale structures produces ocean colour signatures that are in close correlation to thermal ones (Arnone et al., 1990; Taupier-Letage et al., 2003). Drifting buoys deployed in adequate positions are also a useful means to track the eddies' evolution, since they can be entrained by them and in some cases follow their motion for much longer periods than moored instruments. Salas et al. (2002) presented a clear example of how a combination of infrared images and drifting buoy trajectories can provide very valuable information on coastal mesoscale eddies evolution in the Algerian basin.

The changes in sea surface elevation caused by the presence of intense eddies such as AEs suggest another possibility for detecting them and following their evolution. Radar altimeters operated from orbiting satellites measure the surface elevation and therefore, although the spatial resolution of this measurement is lower than the one offered by infrared and optical radiometers, they have the advantage of detecting eddy structures even if there are no clear temperature or colour gradients associated with them. Also, radars are not affected by the presence of clouds in the sampled area. The combination of several altimeters can provide the suitable spatial and temporal resolutions for sampling marine eddies in open oceans (e.g. Wilkin and Morrow, 1994; Le Traon et al., 1998) and even in the Mediterranean Sea (Vignudelli, 1997; Ayoub et al., 1998; Bouzinac et al., 1998).

In this paper we present some results from an experiment carried out in 1998 in the western part of the Algerian basin, where a very deep (as proven by in situ data, Ruiz et al., 2002) AE was sampled with surface drifting buoys and simultaneously tracked on maps of surface elevation obtained from satellite altimeter measurements. We present here the complete drifters' trajectories, analysed in detail in another paper by Salas (2003), and show the coherence between the evolution of the eddy as detected in this data set and the one obtained from altimeter measurements following an objective tracking method developed by Isern-Fontanet et al. (2003). Our objective is to validate this eddy tracking method in the Algerian basin using the independent information provided by the drifters' trajectories.

\section{ALGERS98 CRUISE}

One of the tasks of the European Union MATER (Mass Transfer and Ecosystem Response) project (1996-1999, second phase of the Mediterranean Targeted Project) was the interdisciplinary study of the mesoscale instabilities generated by the Algerian Current. This included a series of cruises in the west (ALGERS) and the east (ELISA) of the basin. The first ALGERS cruise, carried out in October 1996, focused on sampling a coastal instability (Font et al., 1998; Morán et al., 2001; Salas et al., 2002), while the second one in May 1998 focused on sampling an open sea eddy (Isern-Fontanet et al., 2000; Ruiz et al., 2002; Salas, 2003). This eddy, labelled as 98-1 in a paper that followed the evolution of several AEs through satellite infrared imagery (Puillat et al., 2002), is used here as a tracking case study.

From 18 to 27 May 1998 the ALGERS98 cruise was carried out on board the Spanish $R / V$ Hes- 
pérides. A large surface eddy nearly $140 \mathrm{~km}$ in diameter had been detected at the end of April in NOAA SST images centred at $38^{\circ} \mathrm{N} 2^{\circ} \mathrm{E}$ (e.g. using the German DLR GISIS server, see processing details in http://eoweb.dlr.de). Successive satellite images (like the one in Fig. 2) indicated that it was moving to the west at about $2-3 \mathrm{~km} /$ day. Thanks to an onboard satellite receiving station (Sea Space Terascan HRPT), the surface thermal structure was later precisely located in real time during the survey, south of Formentera island. The strategy of the cruise was designed in order to cross the eddy in different directions with underway measurements (thermosalinograph, ADCP, XBTs, and a towed undulating CTD in the top $120 \mathrm{~m}$ ). The CTD data at fixed stations confirmed that it was a deep anticyclonic eddy (Ruiz et al., 2002).

Fifteen surface drifting buoys (SERPE-IESM model SCV40 V3, with ARGOS transmitter) were released across the eddy following an almost northsouth diameter. They were of the classical TOGAWOCE standard type drogued with a $10 \mathrm{~m}$ long holy sock at a mean depth of $10 \mathrm{~m}$. The drifters' positions tracked by satellite were received directly on board with the HRPT station, and through the ARGOS service after the end of the cruise. They were tracked during a variable number of days, until transmission stopped due to failure of the system at open sea (or it may have been damaged or captured by a vessel) or, more commonly, until reaching the coast. Similar Lagrangian drifters had been successfully used to follow the evolution of coastal mesoscale structures during the ALGERS96 cruise (Font et al., 1998; Salas et al., 2001, 2002). Table 1 summarises the information of the individual drifters including the deployment time and location, and time and position for the last usable localisation by the ARGOS system.

\section{RADAR ALTIMETER MEASUREMENTS}

Despite the weak signal amplitude $(10-20 \mathrm{~cm})$ and the coarse space and time resolution of the satellite altimeters tracks at this latitude, several studies have shown the reliability of the satellite altimetric data for analysing the dynamics of the Mediterranean sea (Vázquez et al., 1996; Ayoub et al., 1998; Iudicone et al., 1998; Larnicol et al., 2002), particularly in the Algerian basin (Vignudelli, 1997; Bouzinac et al., 1998). In this paper we use Sea Level Anomalies (SLA) obtained from altimeter measurements instead of absolute sea height, due to the still poor knowledge of the marine geoid that does not allow the absolute oceanographic signal to be obtained from the satellite data. SLA maps of the Mediterranean Sea are regularly produced by Collecte Localisation Satellites (CLS) in Toulouse, France, from the combination of data of the ERS and TOPEX/Poseidon altimeters, by subtracting a four-year mean value from the actual measurements. Besides the usual corrections, data are low-pass filtered to reduce altimetric noise and SLA maps are built on a regular grid of $0.2 \times 0.2$ degrees every 10 days using an improved space/time objective analysis method (Larnicol et al., 1995; LeTraon et al., 1998).

For the present study we extracted SLA maps of the Algerian basin $\left(35.5^{\circ}-40^{\circ} \mathrm{N}, 2^{\circ} \mathrm{W}-10^{\circ} \mathrm{E}\right)$ for the period February to November 1998 (like the one shown in Fig. 3). From these maps surface velocities were computed using SLA horizontal gradients and

TABLE 1. - Deployment information and last localisation at sea by the satellite ARGOS system of the drifters released during ALGERS98

\begin{tabular}{|c|c|c|c|c|c|c|c|c|c|}
\hline \multirow{2}{*}{$\begin{array}{l}\text { Float } \\
\text { ID }\end{array}$} & \multicolumn{4}{|c|}{ Deployment } & \multicolumn{4}{|c|}{ Last localisation } & \multirow{2}{*}{$\begin{array}{c}\text { Days } \\
\text { tracked }\end{array}$} \\
\hline & Date & Time & Lat & Lon & Date & Time & Lat & Lon & \\
\hline 18720 & $19-05-98$ & $21: 27: 30$ & 381725 & 011514 & $04-08-98$ & $17: 40: 35$ & 413448 & 0023256 & 77 \\
\hline 18719 & $20-05-98$ & $00: 05: 41$ & 381118 & 011612 & $01-06-98$ & $19: 34: 43$ & 380123 & 0010744 & 12 \\
\hline 18718 & $20-05-98$ & 02:40:00 & 380648 & 011939 & $15-10-98$ & $17: 58: 02$ & 390625 & 0013047 & 148 \\
\hline 18726 & $20-05-98$ & 05:50:00 & 380206 & 012206 & $16-08-98$ & 07:00:43 & 372924 & 3583130 & 88 \\
\hline 18727 & $20-05-98$ & 09:05:19 & 375751 & 012257 & $23-06-98$ & $06: 51: 29$ & 375519 & 3595259 & 34 \\
\hline 18723 & $20-05-98$ & $12: 51: 39$ & 375205 & 012545 & $29-08-98$ & $14: 33: 24$ & 383448 & 3590152 & 101 \\
\hline 18717 & $20-05-98$ & $16: 40: 00$ & 374645 & 012617 & $27-06-98$ & $07: 01: 21$ & 374543 & 3594410 & 38 \\
\hline 18714 & $20-05-98$ & $19: 35: 29$ & 374147 & 012855 & $29-06-98$ & $15: 55: 38$ & 375147 & 3592458 & 40 \\
\hline 18713 & $20-05-98$ & $23: 55: 17$ & 373812 & 013137 & $05-07-98$ & $03: 13: 06$ & 383340 & 3595259 & 45 \\
\hline 18721 & $21-05-98$ & $02: 45: 00$ & 373314 & 013507 & $26-06-98$ & $07: 23: 19$ & 381619 & 3594052 & 36 \\
\hline 18725 & $21-05-98$ & 05:50:00 & 372758 & 013445 & $30-06-98$ & $05: 55: 14$ & 381142 & 0004901 & 40 \\
\hline 18715 & $21-05-98$ & $09: 45: 00$ & 372310 & 013825 & $14-08-98$ & $19: 02: 26$ & 355754 & 0000531 & 86 \\
\hline 18722 & $21-05-98$ & 13:00:00 & 371650 & 013902 & $05-06-98$ & $15: 08: 12$ & 383304 & 3595208 & 15 \\
\hline
\end{tabular}




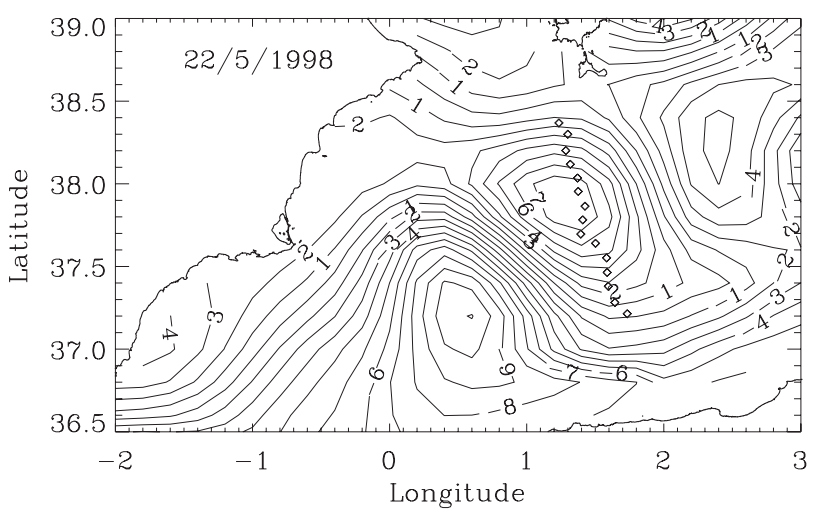

FIG. 3. - Sea Level Anomaly (SLA) map of the Algerian basin on 25 May 1998. Eddy 98-1 appears as a relative maximum crossed by the points where the drifters were released. The average SLA for the area has been removed. Units are $\mathrm{cm}$.

assuming geostrophic balance. The resulting time series of geostrophic velocity maps were used to automatically identify and track mesoscale eddies by means of the methodology developed by IsernFontanet et al. (2003), based on the Okubo-Weiss parameter (Okubo, 1970; Weiss, 1991) that measures the relative contribution of deformation and vorticity in a velocity field. Taking into account the characteristics of two-dimensional flow fields (Hunt et al., 1988; Chong et al., 1990; Jeong and Hussein, 1995), eddy cores can be identified as the simply connected regions with high negative values of the Okubo-Weiss parameter, with a threshold usually based on the statistical properties of the turbulent velocity field (Elhmaïdi et al., 1993). See IsernFontanet et al. (2003) for details on this methodology and its application to altimeter SLA maps.

\section{RESULTS AND CONCLUSION}

The drifters' trajectories during the first week after release (Fig. 4) clearly indicated an anticyclonic sense of rotation collocated with the eddy structure, as revealed by the different hydrographical data sets. Besides the almost circular horizontal density distributions in the surface layers and the typical depression on isopycnal surfaces, the on-board Acoustic Doppler Current Profiler records also displayed a clockwise rotation (Ruiz et al., 2002). The successive positions of the drifters presented the image of an almost solidbody rotation in an inner zone of $80 \mathrm{~km}$ diameter, whose edge corresponded to the maximum of tangential velocity $(40-50 \mathrm{~cm} / \mathrm{s})$.

Figure 5 shows the complete set of trajectories as derived from the drifters' positions computed by the

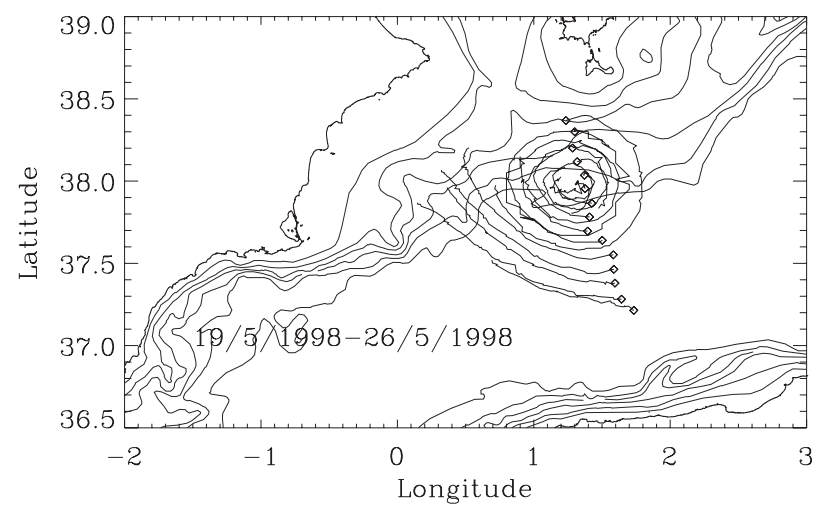

FIG. 4. - The trajectories of the drifters during the first week after deployment mark the position of the anticyclonic eddy. The release sites (indicated) were not completely symmetric around the eddy centre, so the last drifters in the south lie outside the eddy core and tend to leave it. Different bathymetric contours are indicated (200, $500,1000,1500,2000$ and $2500 \mathrm{~m}$ ).

ARGOS system (on average 6-8 times per day). After deployment all the drifters, except the four southernmost ones, started looping around the eddy centre with rotating periods of up to 10 days. During the following weeks we observed how the anticyclonic motion continued as the eddy was drifting to the west and becoming elongated in a northeast-

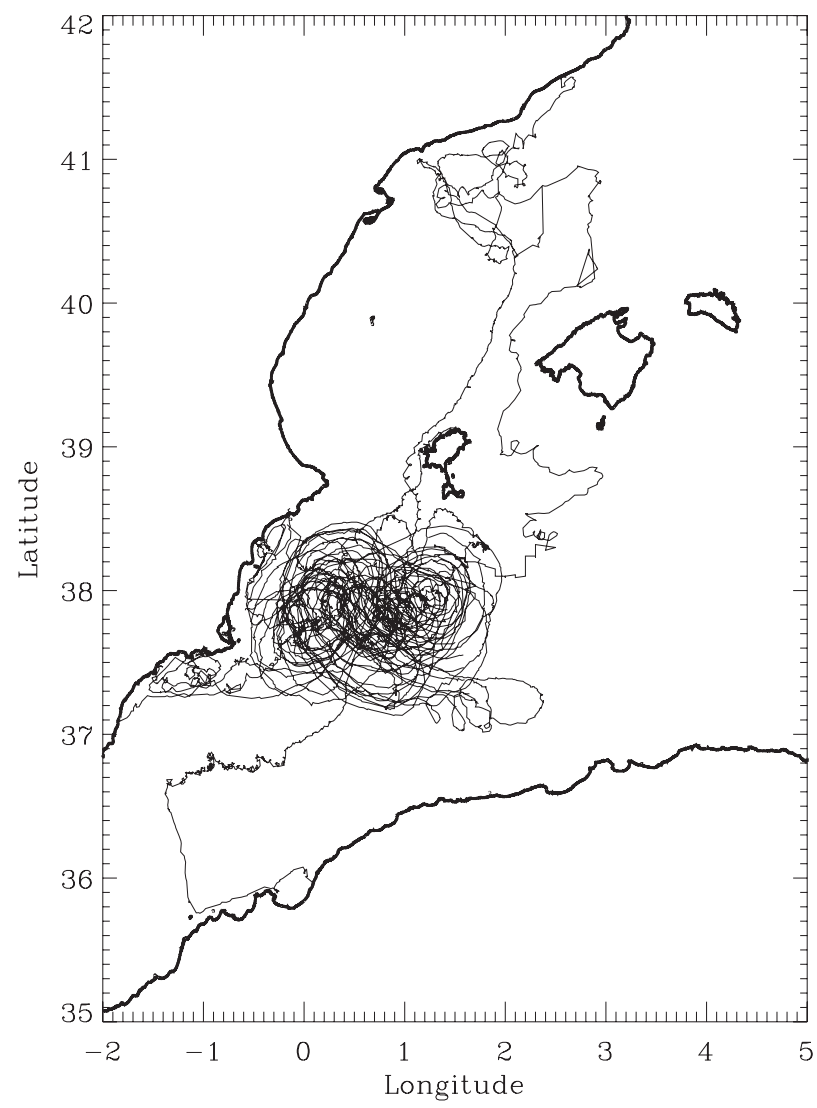

FIG. 5. - Complete set of trajectories (consecutive ARGOS locations, without filtering) from the drifters released on 19-21 May 1998 until they ceased to provide valid data. 

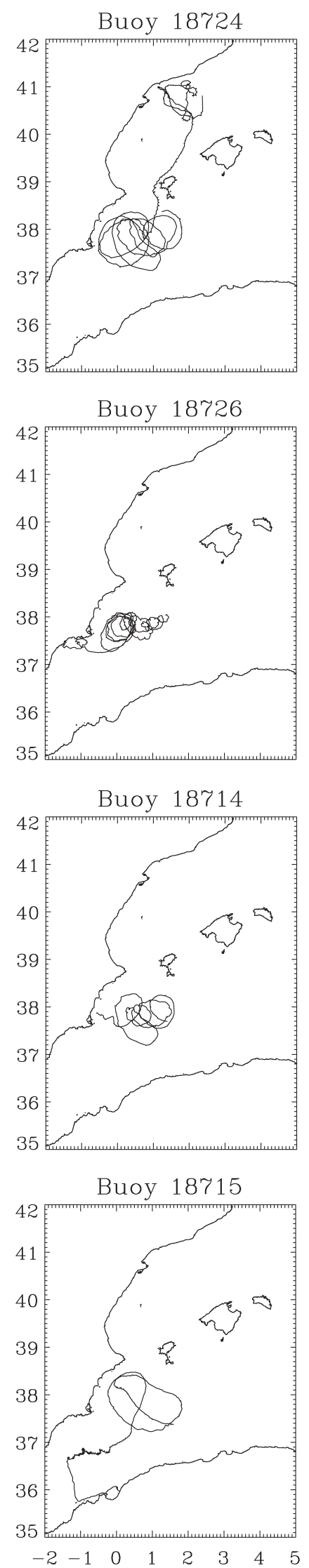

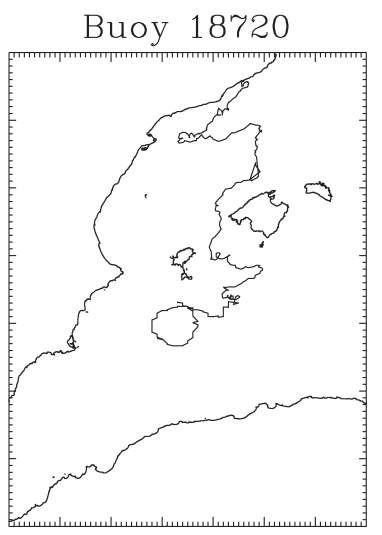

Buoy 18727

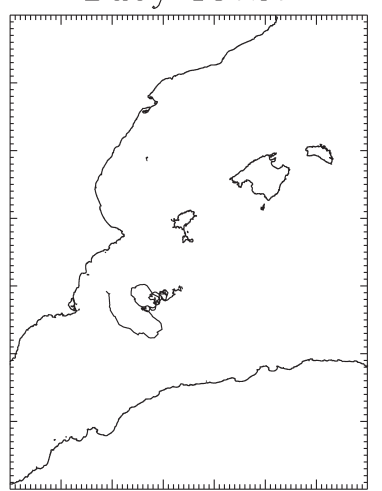

Buoy 18713

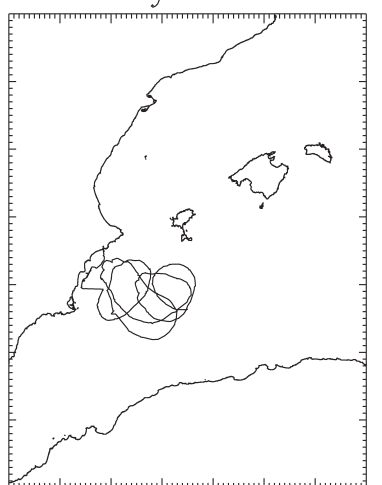

Buoy 18722

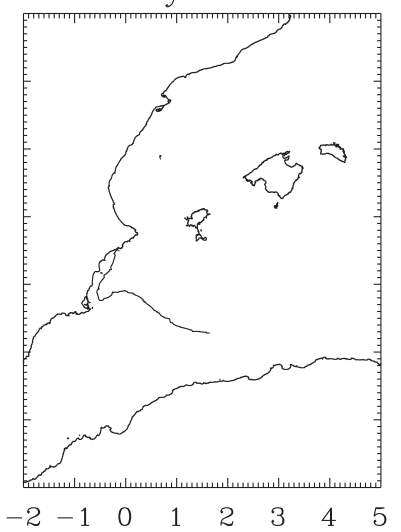

Buoy 18719

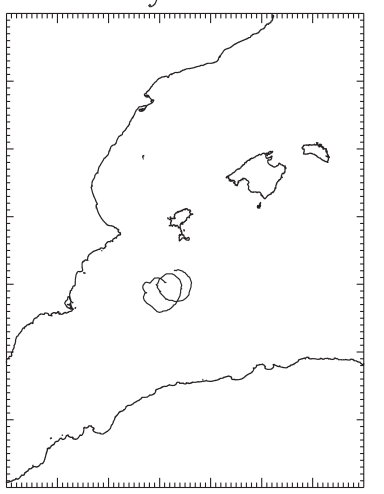

Buoy 18723

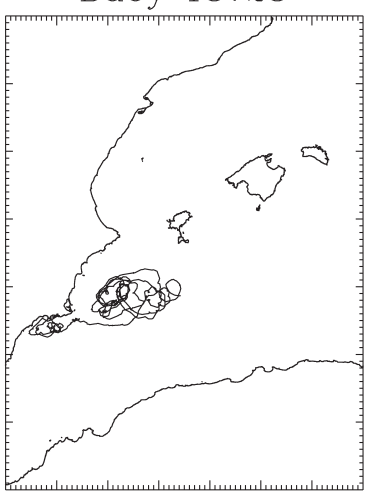

Buoy 18721

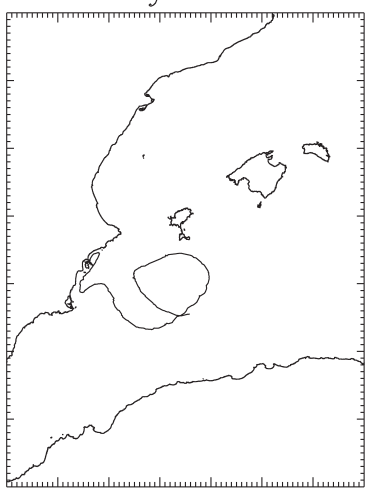

Buoy 18716

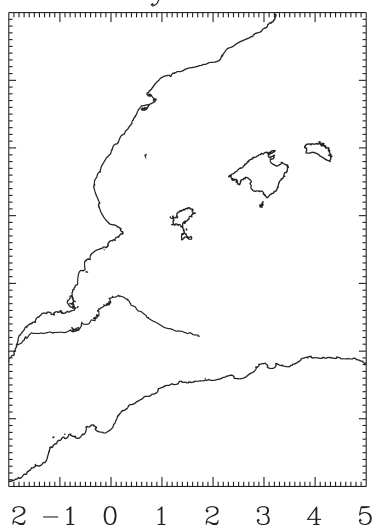

FIG. 6. - Individual trajectories of the 15 ALGERS98 Lagrangian drifters presented in the order in which they were launched from N to S 

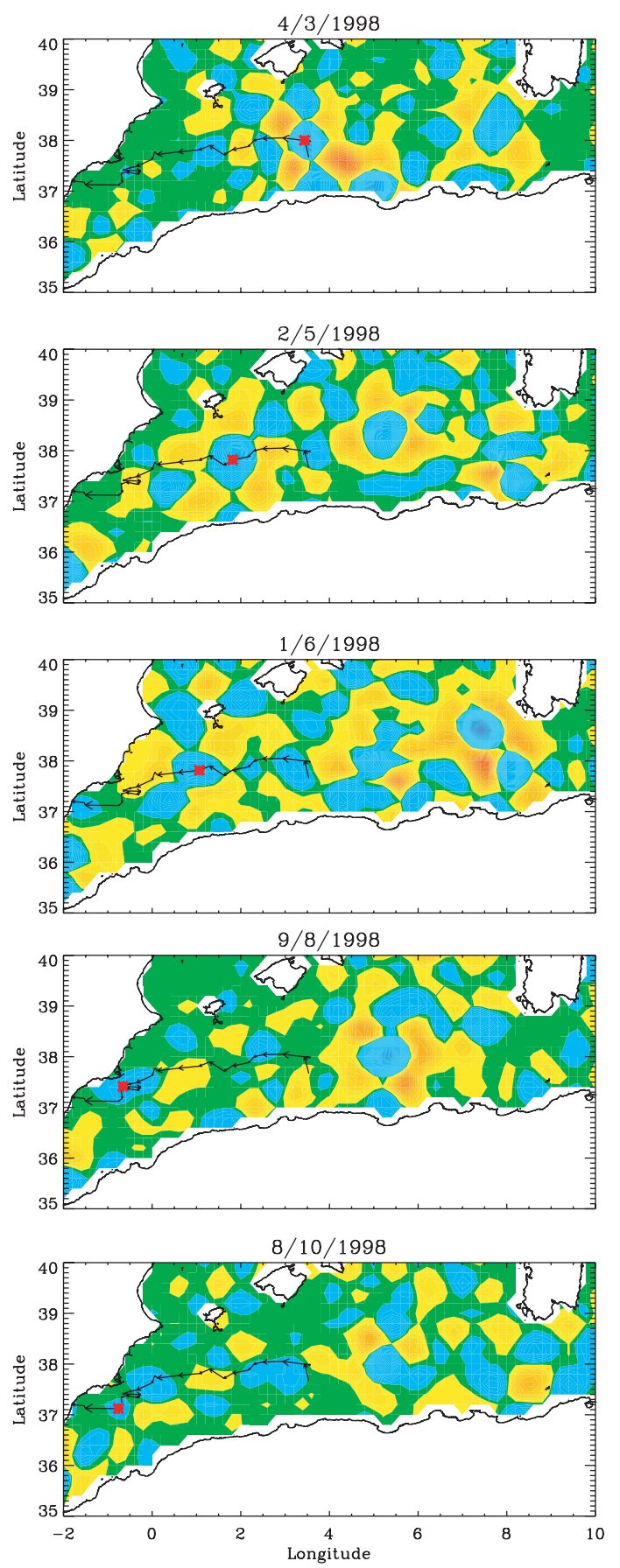
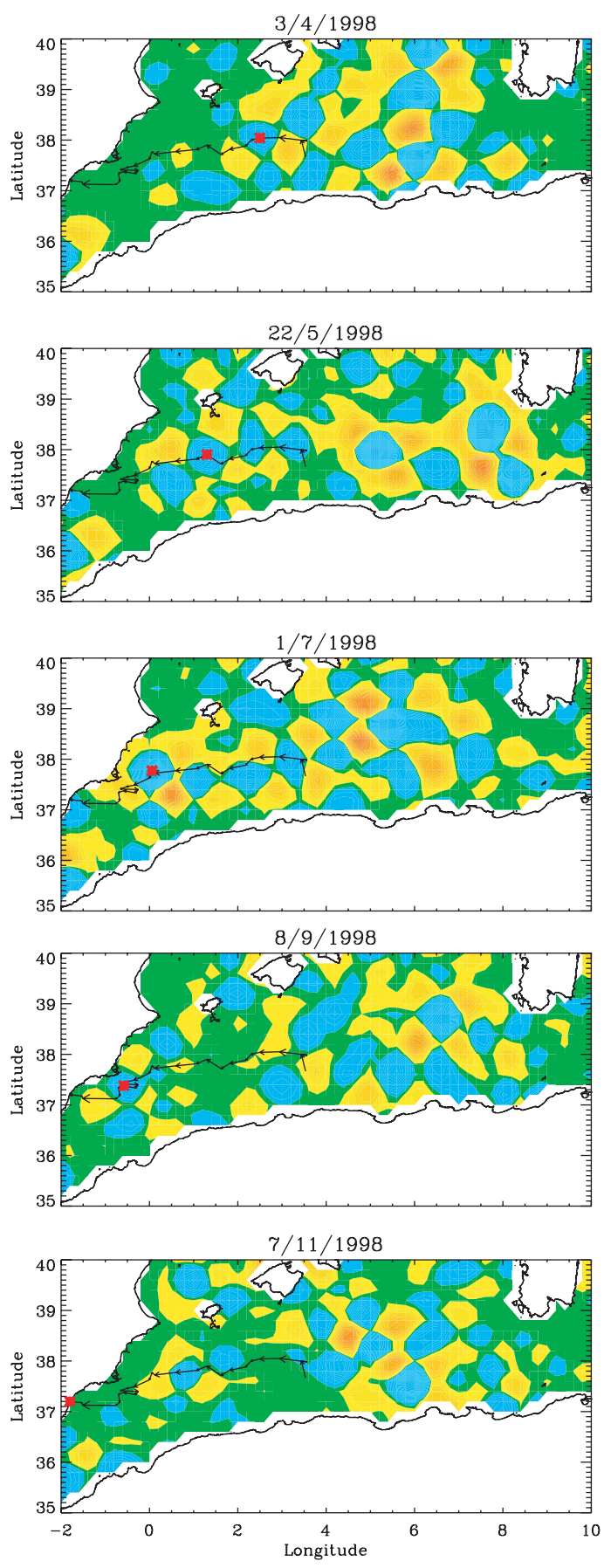

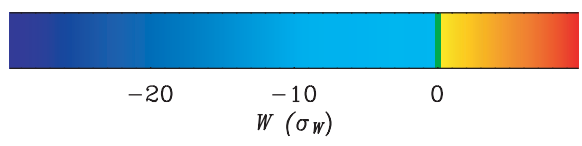

FIG. 7. - Distribution of the Okubo-Weiss parameter in the Algerian basin obtained from altimetric SLA maps during 9 consecutive months (plus the map closest to the drifters' release date). The position of eddy 98-1's centre and its full trajectory is indicated in each map. The units for $W$ are s-2, but the colour scale represents relative values with respect to $\sigma_{W}$. Blue areas correspond to eddy cores ( $\left.W<-0.2 \sigma_{W}\right)$, yellow-red ones to circulation cells $\left(W>0.2 \sigma_{W}\right)$ and green indicates the background field $\left(-0.2 \sigma_{W}<W<0.2 \sigma_{W}\right)$

southwest direction, probably due to the increasing interaction with the bathymetry of the Spanish continental slope. Three months after the start of the experiment, in August, the drifters had dispersed, most of them had left the eddy influence and it was no longer possible to track the motion of the overall eddy, which at that time was under strong interaction with the topography and had initiated a destruc- 
tion process. Salas (2003), using infrared satellite imagery and this drifter data set, made an exhaustive study of the evolution of eddy 98-1 from its generation in late January - early February 1998, around $4^{\circ} \mathrm{E}$ in the central Algerian basin, until its decay and finally disappearance in December west of $1^{\circ} \mathrm{W}$. In Figure 6 we present the individual complete trajectories of the 15 surface drifters released in the ALGERS98 experiment.

The Eulerian geostrophic velocity fields derived from altimetric SLA maps were used to obtain an independent and parallel information on the tracking of eddy 98-1. As explained above, the Okubo-Weiss
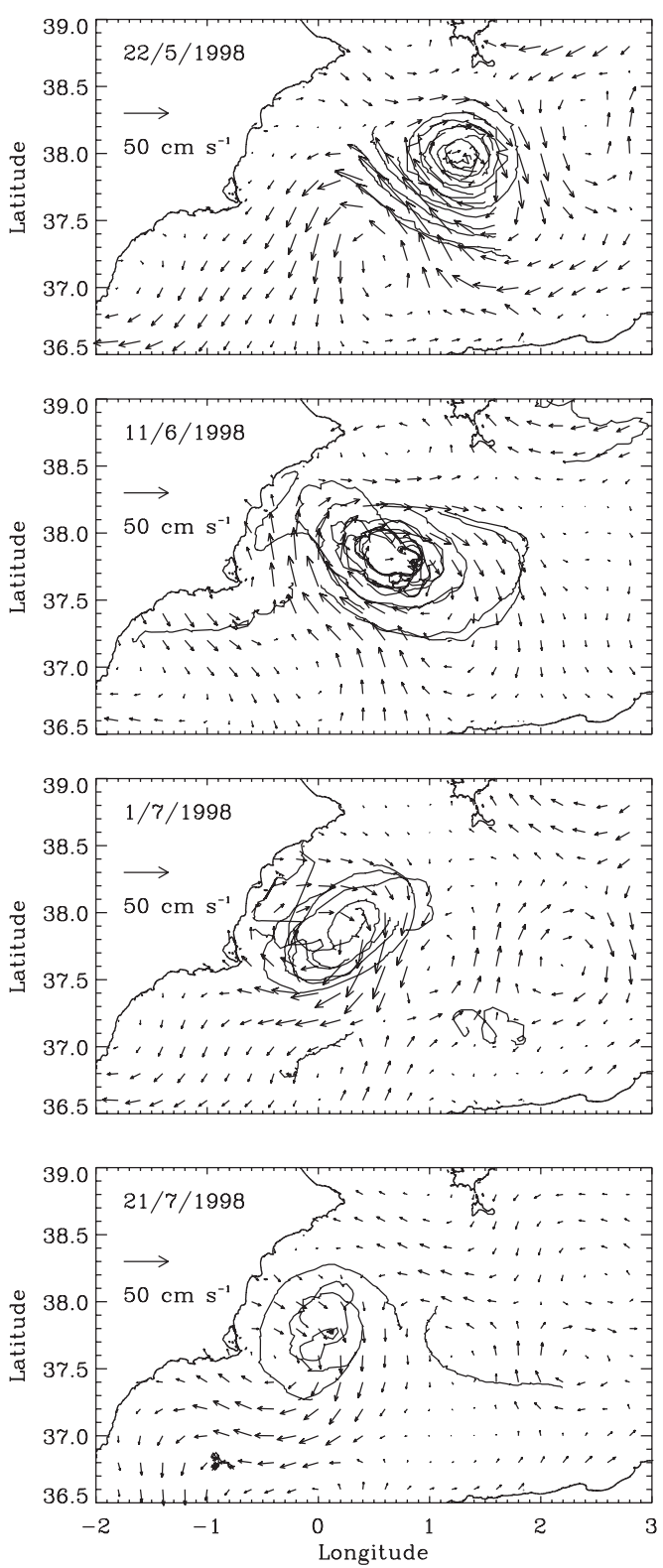

criterion allows the cores of eddies to be identified from these horizontal velocity fields in an objective manner. The parameter is computed in each grid point as (Provenzale, 1999)

$$
W=\sigma_{n}^{2}+\sigma_{s}^{2}-\omega^{2}
$$

where $\sigma_{n}, \sigma_{s}$ and $\omega$ are respectively the normal and the shear component of strain, and the vorticity of the flow defined by

$$
\sigma_{n}=\frac{\partial u}{\partial x}-\frac{\partial v}{\partial y}, \quad \sigma_{s}=\frac{\partial v}{\partial x}+\frac{\partial u}{\partial y}, \quad \omega=\frac{\partial v}{\partial x}-\frac{\partial u}{\partial y},
$$
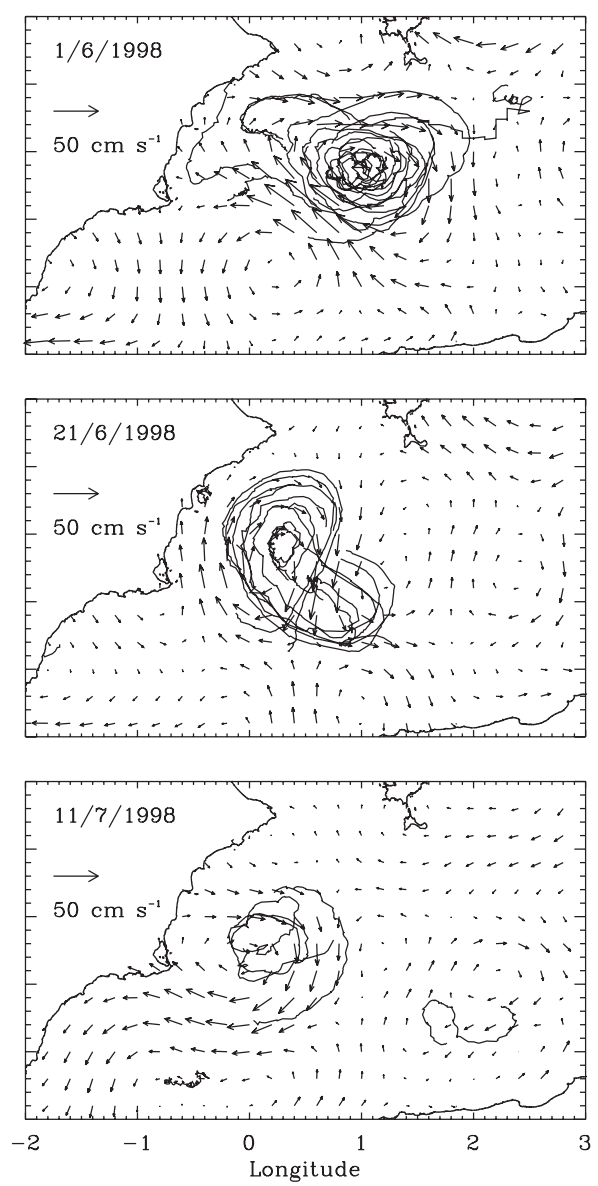

FIG. 8. - Trajectories of ALGERS98 drifters in periods of 10 days overlapped to contemporaneous surface geostrophic velocity field obtained from altimetric SLA maps from May to July 1998 


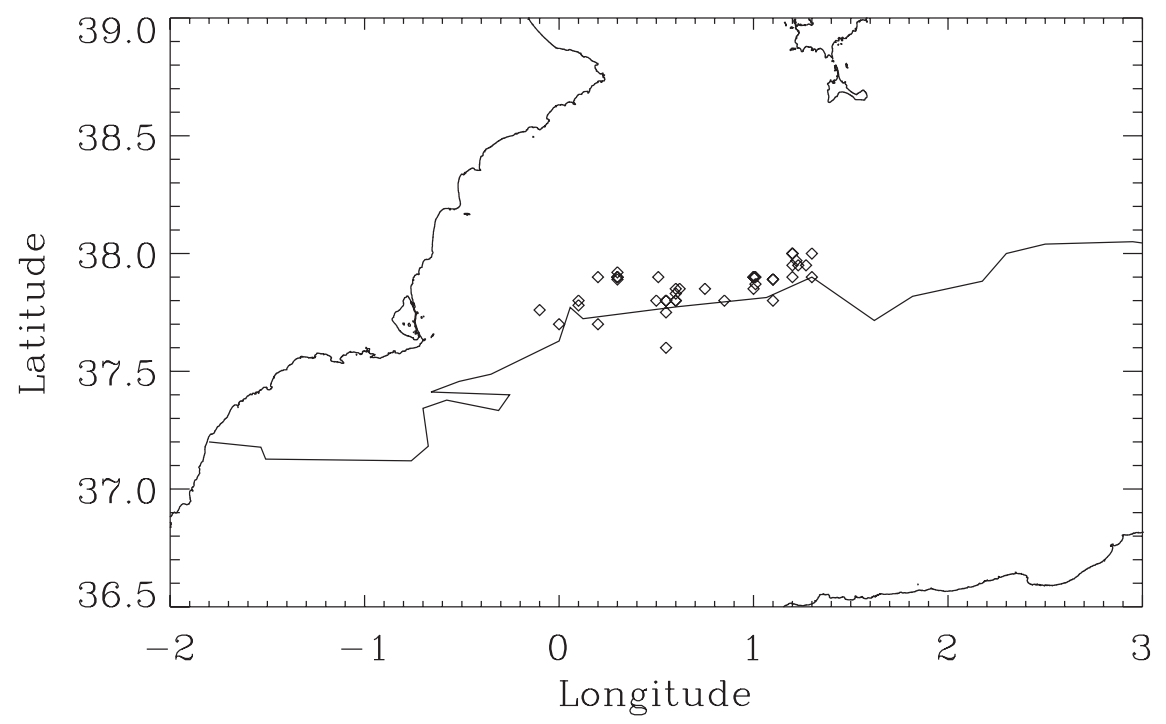

FIG. 9. - Trajectory of the eddy centre as detected with the Okubo-Weiss criterion (solid line) and positions of this centre determined using closed drifter loops (diamonds)

Areas with $W<0$ are vorticity-dominated or elliptic regions and correspond to the inner part of eddies (core), while $W>0$ indicates strain-dominated or hyperbolic regions corresponding to the external part of the eddy (circulation cell). Small positive and negative values of the parameter are characteristic of the background field. To allow a clear discrimination from the background field, we applied the convention of considering an eddy core to be a closed area in which the value of the Okubo-Weiss parameter was lower than -0.2 times the standard deviation of the parameter distribution all around the Mediterranean Sea (Isern-Fontanet, 2003). These areas are indicated in blue on the maps presented in Figure 7, which show the evolution of the horizontal distribution of $W$ at surface from March to November 1998 in steps of nearly one month. We can easily extract from this by continuity the position and extension of $98-1$ 's core in the full time series of surface maps (one every ten days, not shown here, the same frequency as SLA maps built by CLS), and compute the average westward propagation velocity of the eddy centre, which was 2.7 $\mathrm{km} /$ day. It should be taken into account that this method separates the eddy cores neatly, while the circulation cells do not display a similar axial symmetry, have a higher degree of temporal variability and are more smoothly embedded in the background field (Isern-Fontanet et al., 2004). Other means of observing ocean eddies, such as SST images and drifters' trajectories, do not discriminate the two regions, and therefore they usually highlight eddies as areas bigger than their cores.
Both systems of tracking this eddy (Lagrangian from drifters and Eulerian from SLA maps) are first compared in Figure 8 by overlapping over geostrophic velocity maps the drifters' trajectories corresponding to a period from 5 days before to 5 days after the map date. The maps were constructed from the nearest date to the ALGERS98 cruise (22 May) until late July, the last occasion on which closed drifters' trajectories allowed the eddy to be properly located. There is a remarkable match between the position and size of the anticyclonic motion information provided by the two methods, except for the trajectories of some drifters that had clearly been extruded from the eddy.

A quantitative comparison was made by computing the eddy centre as determined by the Okubo-Weiss parameter and by the drifters whenever possible (the seven occasions shown in Fig. 8). From the altimetric data the centre is defined as the mean position of the grid points inside the eddy core. The drifters do not provide a single centre at a given time due to the existence of multiple trajectories looping around the eddy and being not necessarily strictly concentric. All the closed, or almost closed trajectories occurring during each 10-day period were fitted with an ellipse, and the centre of the ellipse is considered to be the centre of the eddy according to that particular drifter. This results in up to 40 single-drifter centres instead of only 7. Figure 9 shows the trajectory of 98-1's centre computed using the Okubo-Weiss parameter (solid line) from March to November, and the positions of this centre (diamonds) computed from the drifters' trajectories on the 7 above-mentioned occasions. 


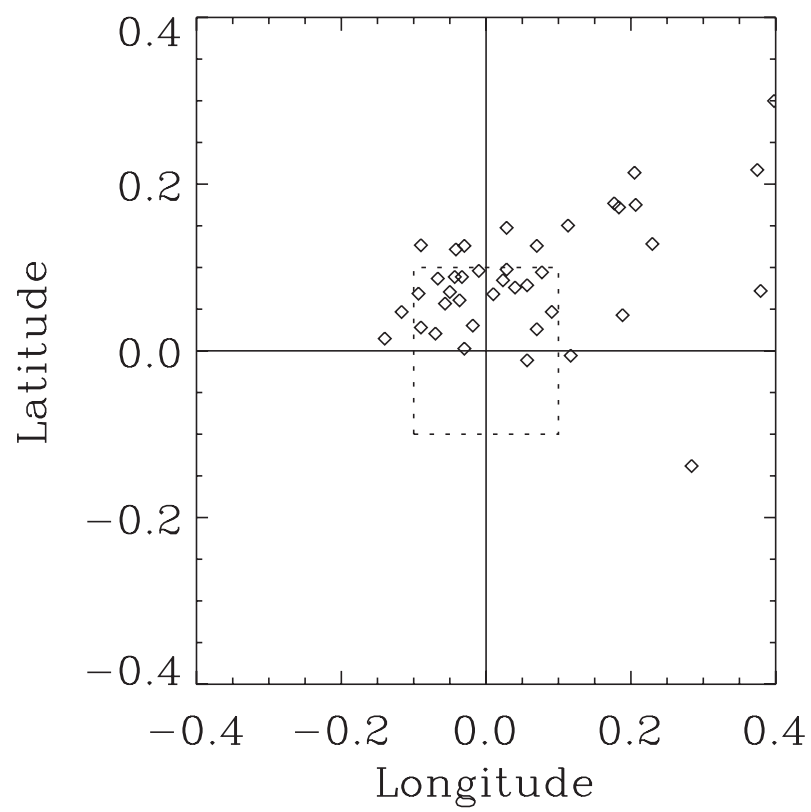

FIG. 10. - Position of the centre of the eddy computed from the drifter data (in different moments and with different drifters) relative to the position determined contemporaneously from the altimeter maps during the two months of coinciding measurements

In Figure 10 we represent the relative position of the centres obtained from the drifters with respect to the simultaneous position obtained from altimetry. The average distance is $15.9 \mathrm{~km}$, with a standard deviation of $10.8 \mathrm{~km}$. To interpret this result it is necessary to consider that the SLA maps, and hence the $W$ distribution, have a grid mesh of $0.2^{\circ} \times 0.2^{\circ}$ (22 x $17.6 \mathrm{~km}$ at this latitude). Therefore, the agreement is highly satisfactory, and in fact in more than $50 \%$ of the cases (see Fig. 10) the centre according to the drifter lies within a $0.2^{\circ}$ side box around the corresponding centre determined by the OkuboWeiss criterion, and consequently both are undistinguishable at the spatial resolution of the altimetric maps. However, on looking at the temporal evolution of the distance between centres (not shown) one can observe an average increase of $0.49 \mathrm{~km} / \mathrm{d}$, that is, there is a slight tendency of the drifters to be "left behind" by the eddy as it is moving westwards according to altimeter data. This can be seen in Figure 8 , where the last three panels display an increasing loss of concentricity between the anticyclonic motion depicted by the drifters' trajectories and by the geostrophic velocity field when the eddy is approaching the coast. We do not have a clear explanation for this fact, although it could be related to the complex dynamics of the interaction of the eddy with the Spanish continental slope (see Fig. 4 for bathymetric information) not reflected in the geostrophic velocity field. Salas (2003), in his study of the long term evolution of AE 98-1 using SST maps, shows in this area a tendency of the eddy to change its motion to the SW following the bathymetric contours, whereas the information we obtained from the altimetric SLA maps does not include this change of direction. In any case one must be careful when examining altimeter data in coastal areas, as the performance of the instrument in measuring sea surface elevation is known to decrease dramatically.

It is not possible to compare the size of eddies from the two methods. Whereas with the OkuboWeiss parameter we can precisely compute an equivalent diameter of the eddy core (with the above-mentioned spatial resolution), we cannot do the same with the Lagrangian information, since the distances of the drifters from the eddy centre depend on their initial deployment position and further evolution and do not provide information on the overall size of the eddy. Only if there is a dense distribution of drifters along an eddy diameter is it possible to obtain this information. In axisymmetric vortices the core boundary coincides with the maximum values of the velocity field (Jeong and Hussain, 1995; Provenzale, 1999). The deployment of 15 drifters across AE 98-1 during ALGERS98 and their further localisation by satellite allowed their initial radial speeds to be computed. As presented in Ruiz et al. (2002), the radial distribution of drifters' velocities indicates that the maximum is found about $40 \mathrm{~km}$ from the centre of the eddy. This gives a diameter of $80 \mathrm{~km}$ that fits very well with the equivalent diameter of $77.2 \mathrm{~km}$ determined from the horizontal distribution of the Okubo-Weiss parameter on 22 May by fitting a circle to the area around $98-1$ where $W$ is below -0.2 (blue zone in Fig. 7).

Another quantitative parameter that can be used to compare the two methods is the translation speed of the eddy centre from its successive positions in the time series of maps. Considering only the period in which both data sets allow this centre to be computed simultaneously (22 May to 21 July), the Okubo-Weiss approach gives an average translation speed of $3.20 \mathrm{~km} / \mathrm{d}$ with a standard deviation of 1.57 $\mathrm{km} / \mathrm{d}$, and the drifters' trajectories indicate an average of $2.63 \mathrm{~km} / \mathrm{d}$ with a standard deviation of 1.49 $\mathrm{km} / \mathrm{d}$. This discrepancy (24\% lower average speed from drifter data) is coherent with the conclusion obtained above from the distances between simultaneous centres. These resulting translation speeds of the order of $3 \mathrm{~km} / \mathrm{d}$ also indicate that the "instanta- 
neous" eddy centre localisations at steps of 10 days (Figs. 9 and 10) must necessarily be noisy.

The final conclusion is that there is a significant agreement in the results despite the different information provided by the two methods, mainly due to the fact that SLA maps contain interpolated and smoothed measurements $(20 \mathrm{~km}$ characteristic error scale), while the drifters' trajectories are in situ data with an accuracy of the order of $500 \mathrm{~m}$ in each individual drifter fix by ARGOS. In addition to this, we must consider that the Okubo-Weiss criterion is based on the geostrophic velocity field, whereas the drifters' motion can also be affected by ageostrophic components. However, a detailed analysis of the surface velocity field during ALGERS98 from CTD, ADCP, drifters and one SLA map (Ruiz et al., 2002) concludes that in this case the ageostrophic velocity is almost negligible. During the further evolution of AE 98-1 examined here (until July 1998) it could happen that the drifters were eventually affected by winds. Although they are designed to minimise the direct drag effect of the wind on the emerged body (drag ratio 1:78 between emerged and submerged parts), the Ekman drift on the upper layer may be responsible for pushing a drifter out of the eddy core and then modifying the conditions that determine its further trajectory.

Using a similar method to that used by IsernFontanet et al. (2004), who compared the detection of AEs (including 98-1) from SLA maps and from in situ CTD data, we have validated here the tracking of one of these eddies using the Okubo-Weiss criterion by comparison with in situ Lagrangian measurements within the resolution discussed in this section.

\section{ACKNOWLEDGEMENTS}

The ALGERS98 cruise on board the $R / V$ Hespérides was part of the INTERMESO project funded by the Spanish National Programme on Environment and Natural Resources (AMB95-0901), and a contribution to the European research projects MATER (funded under contract MAS3-CT96-0051) and ALGERS (European Space Agency ERS AO E102/0). We are grateful to the people on board the Hespérides who contributed to the drifters experiment, and to CLS for providing the altimetric SLA maps generated under contract for the MATER project. We also thank Claude Millot, Stefano Vignudelli and Gilles Larnicol for their comments and suggestions, which helped to improve the manuscript. J. Isern-Fontanet was partially supported by contracts from the GRAC (2FD97-0588) and IMAGEN (REN2001-0802-C02-02) Spanish projects. J. Salas acknowledges a fellowship from the Sistema Nacional de Investigadores (Mexico) during his stay in Barcelona. This study is a contribution to the European Union - GMES Integrated Project MERSEA (Marine Environment and Security for the European Area) funded under contract AIP3-CT2003-502885

\section{REFERENCES}

Arnone, R.A. and P.E. La Violette. - 1986. Satellite definition of the bio-optical and thermal variation of coastal eddies associated with the African Current, J. Geophys. Res., 91: 2351- 2364.

Arnone, R.A., D.A. Wiesenburg and K.D. Saunders. - 1990. The origin and characteristics of the Algerian Current, J. Geophys. Res., 95: 1587- 1598.

Ayoub, N., P.Y. Le Traon and P. De Mey. - 1998. A description of the Mediterranean surface variable circulation from combined ERS-1 and TOPEX/POSEIDON altimetric data, J. Mar. Syst. 18: 3-40.

Benzohra, M. and C. Millot. - 1995. Hydrodynamics of an open sea Algerian eddy, Deep-Sea Res., 18(2): 1831-1847.

Bouzinac, C., J. Vázquez and J. Font. - 1998. CEOF analysis of ERS1 and TOPEX/POSSEIDON combined altimetric data in the region of the Algerian current, J. Geophys. Res., 103: 8059-8071.

Chong, M.S., A.E. Perry and B. Cantwell. - 1990. A general classification of three-dimensional flow field, Phys. Fluids, A2: 765-777.

Elhmaïdi, D., A. Provenzale and A. Babiano. - 1993. Elementary topology of two-dimensional turbulence from a Lagrangian viewpoint and single-particle dispersion, J. Fluid Mech., 257 : 533-558.

Font, J., C. Millot, J. Salas, A. Julià and O. Chic. - 1998. The drift of Modified Atlantic Water from the Alboran Sea to the eastern Mediterranean, Sci. Mar., 62(3): 211-216.

Fuda, J.L., C. Millot, I. Taupier-Letage, U. Send and X. Bocognano. -2000 . XBT monitoring of a meridian section across the western Mediterranean Sea, Deep-Sea Res., 47(11): 2191-2218.

Hunt, J., A. Wray and P. Moin. - 1988. Eddies, stream, and convergence zones in turbulent flows, Proc. CTR Summer Program, Stanford, CA, Center for Turbulence Research: 193-208.

Isern-Fontanet, J. - 2003. Estadística de vòrtex coherents a la Mediterrània: anàlisi de la superfície lliure del mar, $\mathrm{PhD}$ thesis, Dep. Física Aplicada, Univ. Barcelona, 131 pp.

Isern-Fontanet, J., J. Salas, S. Ruiz, J. Font and C. Millot. - 2000. Tracking anticyclonic open-sea eddies in the Algerian basin by altimetry, In: C.R. Bostater Jr., R. Santoleri (eds.), Remote Sensing of the Ocean and Sea Ice 2000, Proc. SPIE, 4172: 37-43.

Isern-Fontanet, J., E. García-Ladona and J. Font. - 2003. Identification of marine eddies from altimetry. J. Atmos. Ocean. Tech., 20: $772-778$.

Isern-Fontanet, J., J. Font, E. García-Ladona, M. Emelianov, C. Millot and I. Taupier-Letage. - 2004. Spatial structure of anticyclonic eddies in the Algerian basin (Mediterranean Sea) analyzed using the Okubo-Weiss parameter, Deep-Sea Res., in press.

Iudicone, D., R. Santoleri, S. Marullo and P. Gerosa. - 1998. Sea level variability and surface statistics in the Mediterranean sea from TOPEX/Poseidon data. J. Geophys. Res., 103: 2995-3011.

Jeong, J. and F. Hussain. - 1995. On the identification of a vortex, J. Fluid Mech., 285: 69-94.

Larnicol, G., P.Y. Le Traon, N. Ayoub, P. De Mey. - 1995. Mean sea level and surface circulation variability of the Mediterranean Sea from 2 years of TOPEX/POSEIDON altimetry, $J$. Geophys. Res., 100(C12): 385-396.

Larnicol, G., N. Ayoub and P.Y. Le Traon. - 2002. Major changes in the Mediterranean sea level variability from 7 years of 
TOPEX/POSEIDON ERS-1/2 data, J. Mar. Syst., 33-34: 63-89. Le Traon, P.Y., F. Nadal and N. Ducet. - 1998. An improved mapping method of multisatellite altimeter data, J. Atmos. Ocean. Tech., 15: 522-534.

Millot, C. - 1985. Some features of the Algerian current, J. Geophys.Res, 90: 7169-7176.

Millot, C. - 1987. Circulation in the western Mediterranean Sea, Oceanol. Acta, 10(2): 143-149.

Millot, C., M. Benzohra and I. Taupier-Letage. - 1997. Circulation in the Algerian basin inferred from the MEDIPROD-5 current meters data, Deep-Sea Res., 44(9-10): 1467-1495.

Morán, X.A.G., I. Taupier-Letage, E. Vázquez-Domínguez, S. Ruiz, L. Arín, P. Raimbaul and M. Estrada. - 2001. Physicalbiological coupling in the Algerian basin (SW Mediterranean): Influence of mesoscale instabilities on the biomass and production of phytoplankton and bacterioplankton, Deep-Sea Res.,48: 405-437.

Obaton, D., C. Millot, G. Chabert d'Hières and I. Taupier-Letage. 2000. The Algerian current: comparisons between in situ and laboratory measurements. Deep-Sea Res., 47(11): 2159-2190.

Okubo, A. - 1970. Horizontal dispersion of particles in the vicinity of velocity singularities such as convergences, Deep-Sea Res., 17: 445-454.

Provenzale, A. - 1999. Transport by coherent barotropic vortices, Ann. Rev. Fluid Mech., 31: 55-93.

Puillat, I., I. Taupier-Letage and C. Millot. - 2002. Algerian eddies lifetime can near 3 years, J. Mar. Syst., 31: 245-259.

Ruiz, S., J. Font, M. Emelianov, J. Isern-Fontanet, C. Millot, J. Salas and I. Taupier-Letage. - 2002. Deep structure of an open sea eddy in the Algerian Basin, J. Mar. Syst., 33-34: 179-195.
Salas, J. - 2003. Evolution of the open-sea eddy ALGERS'98 in the Algerian Basin with Lagrangian trajectories and remote sensing observations, J. Mar. Syst., 43: 105-131.

Salas, J., E. García-Ladona and J. Font. - 2001. Statistical analysis of the surface circulation in the Algerian Current using Lagrangian buoys. J. Mar. Syst., 29: 69-85.

Salas, J., C. Millot, J. Font and E. García-Ladona. - 2002. Analysis of mesoscale phenomena in the Algerian basin from drifting buoys and infrared images, Deep-Sea Res., 49: 245-266.

Taupier-Letage, I. and C. Millot. - 1988. Surface circulation in the Algerian Basin during 1984. Oceanol. Acta, 9 : 119-131.

Taupier-Letage, I., I. Puillat, C. Millot and P. Raimbault. - 2003 Biological response to mesoscale eddies in the Algerian Basin, J. Geophys. Res, 108(C8): 3245, doi:10.1029/1999JC000117.

Vázquez-Cuervo, J., J. Font and J.J. Martínez-Benjamín. - 1996. Observations on the circulation in the Alboran sea using ERS 1 altimetry and sea surface temperature data, J. Phys. Oceanogr., 26(8): 1426-1439.

Vignudelli, S. - 1997. Potential use of ERS-1 and Topex/Posseidon altimeters for resolving oceanographic patterns in the Algerian Basin, Geophys. Res. Lett., 24(14): 1787-1790.

Weiss, J. - 1991. The dynamics of enstrophy transfer in two-dimensional hydrodynamics, Physica D, 48: 273-294.

Wilkin, J.L. and R.A. Morrow. - 1994. Eddy kinetic energy and momentum flux in the Southern Ocean: Comparisons of a global eddy-resolving model with altimeter, drifter and currentmeter data. J. Geophys. Res., 99: 7903-7916.

Scient. ed.: C. Millot 